\title{
DOMACIAS DAS FOLHAS DO PIMENTÃO CAPSICUM ANNUUM L. CULTIVADO EM SOLUÇÕES NUTRITIVAS COM CARENCIA DE MACRONUTRIENTES *
}

\author{
Myrthes A. AdÂmoli de Barros * *
}

\section{RESUMO}

\begin{abstract}
Foram examinadas 1273 folhas, entre novas e adultas do pimentão - Capsicum annuum L., sendo 226 folhas testemunhas e o restante de plantas cultivadas em solucóes nutritivas com deficiencias de macronutrientes (N, Ca, K, Mg, S, P).

Do total de 1273 folhas, 1120 apresentaram domácias do tipo stufo de pelos> e suas variacỏes, locallizadas na face inferior do limbo, nas axilas da nervura principal com as secundárias.

As principais modificaç̃es foram as variaçoes na quantidade e distribuicão dos pelos formadores da estrutura. Nas folhas testemunhas, os pelos das domácias se apresentaram mais longos, mais ondulados e mais grossos do que nas domáclas das folhas do experimento.
\end{abstract}

\section{INTRODUCAO}

O Eng ${ }^{\circ}$ Agr ${ }^{\circ}$ Pedro Dantas Fernandes, em 1971 conduziu um experimento para estudo dos efeitos de carência de macronutrientes em Capsicum annuum $L$, o pimentão, cuja sintomatologia se revela, principalmente, nas folhas, as quais são portadoras de domácias. Por essa razão, interessei-me em examinar todo o material foliar do experimento, mesmo porque não encontrei referências sobre o assunto na literatura, para verificar se a carência dos mencionados nutrientes teria afetado, também, a morfologia das domácias. Aliás, em 1963, estudei com o mesmo objetivo, as domácias das folhas de Coffea arabica L. var. caturra K. M. C. cultivadas com deficiências e excessos de micronutrientes pelo Prof. Dr. Luiz Neptune Menard e verifiquei que houve alteraçōes na sua estrutura.

\section{REVISAO DA LITERATURA}

Trata-se do primeiro estudo sobre modificaçōes na morfologia das domácias nas variedades Avelar e Ikeda de pimentão - Capsucum annuum L,

\footnotetext{
- Entregue para publicagio em 12/11/73.

-* Prof. Assistente Dr. do Depto de Botanica - E.S.A.L.Q.
} 
cultivadas em soluções nutritivas com carência de macronutrientes, baseado, como já mencionei, no material fornecido pelo Eng ${ }^{\circ} \mathrm{Agr}^{\circ}$ Pedro Dantas Fernandes.

\section{MATERIAL}

O material examinado constou de 1273 folhas de pimentão, entre novas e adultas, sendo 226 folhas testemunhas e as demais portadoras dos sintomas de deficiências de macronutrientes.

As plantas de pimentão foram cultivadas pelo Engo Agro Pedro Dantas Fernandes nas seguintes soluções: nutritiva completa, com omissão de cálcio, de potássio, de magnésio, de fósforo, de enxofre e de nitrogênio.

Observei individualmente folha por folha, tanto a face superior como a inferior, com o auxílio do microscópio estereoscópico, anotando as particularidades apresentadas pelas domácias.

\section{ESTUDO MORFOLÓGICO E COMPARATIVO DAS DOMÁCIAS}

\section{Domácia das folhas testemunhas}

As folhas do pimentão cultivado, em solução nutritiva normal, apresentam domácias na página inferior do limbo, caracterizando-se por um agrupamento de pelos na região de confluência da nervura principal com as secundárias e, raras vezes, com as terciárias. Elas se enquadram no tipo «tufo de pelos» dá classificação de domácias de Chevalier \& Chesnais (1941), com as seguintes variações: «pelos raros», «pelos esparsos», «aglomerado de pelos» e «tufo de pelos».

Os pelos que formam as domácias são, geralmente, longos e algumas vezes ondulados. A região correspondente à domácia, na página superior da folha, mostra-se levemente abaulada.

2. Domácias das folhas com carência de macronutrientes

As diferenças observadas nestas domácias dizem respeito ao tamanho, ao número de pelos e à sua disposição no limbo.

Nas folhas portadoras de deficiências de nitrogênio predominaram as domácias dos grupos «pelos esparsos» e «aglomerado de pelos», seguidos dos grupos «tufo de pelos» e «pelos raros». Em 22 folhas não foram encontradas domácias.

Nas folhas com carência de fósforo predominaram as domácias dos grupos «pelos esparsos» e «aglomerado de pélos» seguidos de «pelos raros». Ausência do grupo «tufo de pelos»; 17 folhas sem domácias:

Nas folhas com carência de enxofre predominou o grupo «pelos raros» seguidos de «pelos esparsos», «aglomerado de pelos» e «tufo de pelos». Cerca de 29 folhas sem domácias. 
Nas folhas com deficiência de cálcio predominaram domácias de grupo «pelos raros» e «tufo de pelos». Em 15 folhas houve ausência de domácias.

Nas folhas com carência de magnésio houve predominância dos grupos «pelos esparsos», «pelos raros» e «aglomerado de pelos» com ausência do grupo «tufo de pelos». Em 25 folhas não encontrei domácias.

Quanto às folhas com carência de potássio houve predominância das domácias dos grupos «aglomerado de pelos» e «pelos esparsos», seguidos dos grupos «pelos raros» e «tufo de pelos». Cerca de 22 folhas sem domácias.

Registrei a presença de grande número de ácaros percorrendo as domácias e suas adjacências.

\section{CONCLUSOES}

Do exposto, conclui-se que de certa forma as domácias das folhas do pimentão com carência de macronutrientes revelaram pequenas alterações na aparência, na quantidade e distribuição dos pelos que as compõem.

Houve influência das carências dos macronutrientes na constituição das domácias do pimentão e fato idêntico observei, como já mencionei, com as domácias do cafeeiro, sob o efeito de deficiências e de excessos de micronutrientes.

As presentes observações põem em destaque que as carências e os excessos de nutrientes, sejam macro ou micronutrientes, influem na morfologia e na constituição das domácias das plantas estudadas.

\section{SUMMARY}

MODIFICATION OF THE DOMATIA OF RED-PEPPER «CAPSICUM ANNUUM» L. LEAVES PROVOCATED BY LACK OF MACRONU. TRIENTS.

This paper studies the differences between domatia of normal leaves of Capsicum annuum L. and leaves of plants cultivated with deficiencies of $\mathrm{N}, \mathrm{Ca}, \mathrm{F}, \mathrm{Mg}, \mathrm{S}$ e P. Were studied 1273 leaves, of all ages, 226 of them being leaves of normal plants.

The domatia founded were of the type «en touffe de poils» according to the Chevalier's Classification (1941) and theirs variations, localizated on the dorsal side of the limb, on the axil of midrib with the secondaries oves.

The principal modification was that in the normal leaves the hairs (trichomes) were longer, waver and thicker than those of deficient plants.

\section{LITERATURA CITADA}

1 - CHEVAliER, A \& CHISNAIS, F. - Botanique Sur les domaties des feilles de Juglandáceas. Extraido de C. R. Académie des Sciences 213: 389-392 e 597-601. 1941. 
2 - ADAMOLI DE BARROS, M. A. --Estudo comparativo das domácias de folhas normais e domácias de folhas cujas plantas foram cultivadas com deficiências e excessos de micronutrientes ( $\mathrm{Fe}, \mathrm{Mn}$, Mo, e $\mathrm{Cu}$ ), em Coffea arabica L. variedade caturra K.M.C. - Anais da ESALQ, vol. XX, p. 230 240. 1963.

3 - FERNANDES, Pedro Dantas - Estudos de nutrição mineral do pimentão (Capsicum annuum, L.), variedades Avelar e Ikeda. Absorção e deficiên cias de macronutrientes. Dissertação apresentada à ESALQ, para obtent ção do título de Mestre. 1971. 